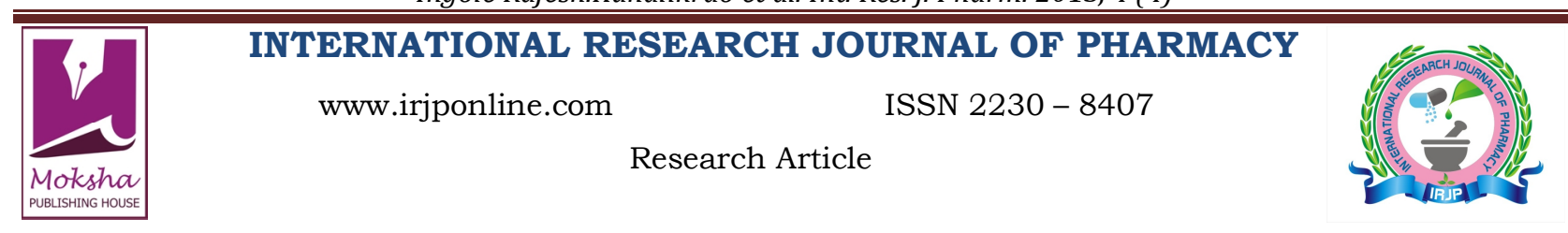

\title{
PHARMACEUTICAL AND ANALYTICAL STUDY OF RASASINDURA CHANDRODAYA RASA
}

Ingole Rajesh.Kundlikrao ${ }^{1 *}$, Khaparde Prakash Hiralal ${ }^{2}$

${ }^{1}$ Associate Professor, Post Graduate Department of Rasashastra \& B.K. ,YAMC \& RC, Kodoli, Kolhapur, Maharashtra, India

${ }^{2}$ Professor, Rasashatra B.K. dept. Dean Govt. Ayurved College, Osmanabad, Maharashtra, India

Email: rajesh.ingole9@gmail.com

Article Received on: 07/02/13 Revised on: 07/03/13 Approved for publication: 11/04/13

DOI: $10.7897 / 2230-8407.04423$

IRJP is an official publication of Moksha Publishing House. Website: www.mokshaph.com

(C) All rights reserved.

\section{ABSTRACT}

Rasashatra is a science of minerals and its main aim to gain Drama, Artha, Kam, Moksha. In Rasashatra there are many methods to control or convert the mercury in the form which is beneficial to our body for curing the disease in certain dose which is called Murchchana. Kajjali, Parpati, Kupipawa rasayana, pottali rasayana all of these are the different methods for the murchchana of Parada. Among these Kupipakwa method is unique and somehow difficult. So here is an attempt in this study to prepare the Rasasindura and chandrodaya rasa by traditional method and do analytical study of obtained sample.

Key Words: Kupipakwa, Rasasindura, chandrodaya rasa, Murchchana.

\section{INTRODUCTION}

In present era Ayurvedic physicians profusely use medicines made up from minerals, metals, gems and animals (pranij) as well as vegetable products. Among these preparations from minerals, metals supposed to be harmful to our body as per western medicine. It is very surprising to know that in Rasashastra text the side effects or adverse effects are already mentioned if we use this medicine not made properly. Ayurvedic physicians are of the view that different Ayurvedic pharmaceutical processing like Shodhana, Marana, Murchchana, Jarana etc. convert metallic preparations into non-toxic.

Rasasindura and Chandrodaya Ras are herbo mineral preparation. These are prepared by Kupipakva method. In Rasasindura Kajjali prepared of Shuddha Parada and Shuddha Gandhaka is given the Bhavana of Vatankura Swarasa. Gandhaka Jarana plays an important role in enhancing the potency of mercury. It has been claimed in the text that mercury treated with the process of Gandhaka Jarana, becomes highly potentiated i.e. it acquires many pharmacological and therapeutic properties. Dhatu yukta Kupipkva Rasayana has its more importance.

Chemically both Rasasindura and Chandrodaya Ras are Hgs but after doing XRD test (X-Ray Diffraction) Gold found in Chandrodayarasa's upper part of medicine in trace amount.

\section{Aims and Objectives}

- Pharmaceutical study of Rasa sindur according to Rastarangini 6/162-167

- Pharmaceutical study of Chandyodaya Ras according to Rasendrasar sangraha-Rasayana vajikaran 65-66

- To Study the ancient and Modern Parameters in analytical studies

\section{MATERIAL AND METHODS \\ Materials}

Shudha Parada $(\mathrm{Hg})$

Shudha gandhaka(S)

Suwarna patra(Au)

\section{Methods}

Preparation of Rasasindura ${ }^{1}$
Ref : Rasatarangini 6/162-167

Materials : Suddha Parada : 100 gm

Suddha Gandhaka : 100 gm

Method : Kupipakva Method (Bahirdhuma Viddhi )

Equipments : Valuka Yantra, Prepared Kachakupi,

Different Shalakas, Cork, copper coin, Torch,etc.

\section{Procedure}

The whole procedure was divided into 3 phases

(I) Purva Karma (II) Pradhana Karma (III) Paschat Karma

\section{Purvakarma}

Preparation of Kajjali : for this purpose Suddha Parada and Shuddha Gandhaka were weighed accurately, mixed together in mortar(Khalva) and trituration was started till the Kajjali became completely Nischandra and black. After this Vatankura Swarasa Bhavana was given.( Three Time).After that Kajjali was cautiously filled up in the Kachakupi which had seven layer of Kapada Mitti.

\section{Pradhana Karma}

In the Pradhana Karma the Mrudu Agni : Room temp. to $200^{\circ} \mathrm{C}$ ( $8 \mathrm{hrs}$ ).Madhyam Agni : $200-450^{\circ} \mathrm{C}$ ( $8 \mathrm{hrs}$ ). Tivra Agni : $450-650^{\circ} \mathrm{C}$ ( $8 \mathrm{hrs}$ ).was given in valuka yantra. ${ }^{2}$

\section{Paschata Karma}

The bottle was broken and the sublimate deposited at the neck of Kachakupi was collected and weighed.

\author{
Preparation of Chandrodayarasa ${ }^{3}$ \\ Materials \\ Suddha Suwarnapatra : $05 \mathrm{~g}$ \\ Suddha Parada : $40 \mathrm{~g}$ \\ Suddha Gandhaka $\quad: 80 \mathrm{~g}$ \\ Method : Kupipakva Method (Bahirdhuma Viddhi ) \\ Equipments : Same as Rasasindura
}

\section{Procedure}

The whole procedure was divided into 3 phases like above method.

Shuddha Suwarna patra mixed in the parada and then amalgam of parada and suwarna made after seven days trituration. After then Suddha Gandhaka churna double in 
quantity of parada added into this mixture and trituration till the Kajjali became completely. After confirmation of Nischandratva of Kajjali, Vatankura

Swarasa Bhavana was given.( Three Time) And Mrudu, Madhyam, Trivra Agni was given.

\section{RESULT}

\section{Analytical Study}

This study we can divided in to two parts.

- Ancient methods

- Modern methods

\section{Ancient methods}

Raw mineral drugs are standardized by characters like colour, size, shape, shining, weight, etc. Prepared Rasa Aushadhis are standardized by parameters like its colour, fineness and its different tests i.e. Bhasma examination like Rekhapurnatva, Varitaratva, etc. In the present context, the raw materials are Parada, Gandhaka, Suwarna intermediate product is Kajjali and the final product is Rasasindura and Chandrodaya Rasa

\section{Ancient Methods}

Rasasindura

Rupa (colour) : Red black Shiny

Rasa (Test) :

Gandha (Smell) : Nirgandha

Sparsa (Tough) : Shita

Rekhapurnava : Present

Varitar : Present

Chandrodaya rasa : Rupa (colour) : Red Shiny Gandha (Smell) : Nirgandha

Sparsa (Tough) : Shita

Rekhapurnava : Present

Varitar : Present

Table 1

\begin{tabular}{|c|c|c|c|c|}
\hline Test & Kajjali & Suwarna Kajjali & Rasasindur & Chandrodayarasa \\
\hline Loss on Ingnition & 0.71 & 0.63 & 0.58 & 0.47 \\
\hline Loss on drying & 2.10 & 3.00 & 2.10 & 2.80 \\
\hline Ash value & 2.40 & 1.20 & 5.24 & 0.0 \\
\hline Acid insoluble ash & 0.04 & 0.03 & 0.08 & 0.30 \\
\hline Water soluble ash & 0.30 & 0.35 & 0.28 & 82.30 \\
\hline Mercury as Hg & 54.62 & 28.72 & 80.93 & 12.96 \\
\hline Sulphur as S & 39.72 & 70.12 & 14.34 & \\
\hline
\end{tabular}

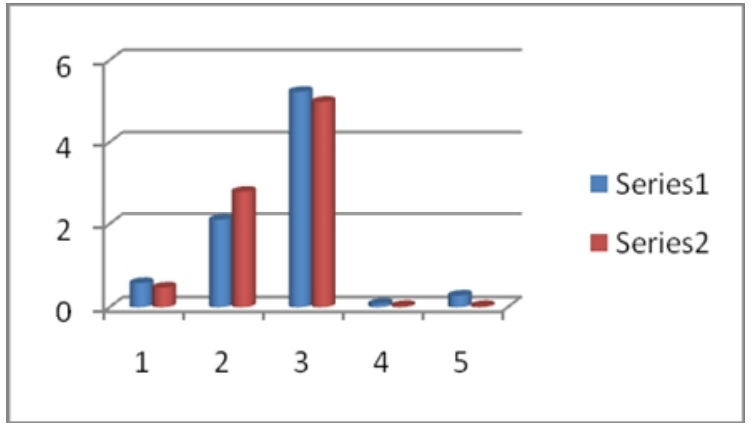

Bar Diagram 1: Analytical Study of Kajjali And Suwarna Kajjali 1.- Loss on Ignition, 2.Loss on drying at $110^{\circ} \mathrm{c}, 3$. Total ash, 4. Acid insoluble ash, 5. water soluble ash $\%$

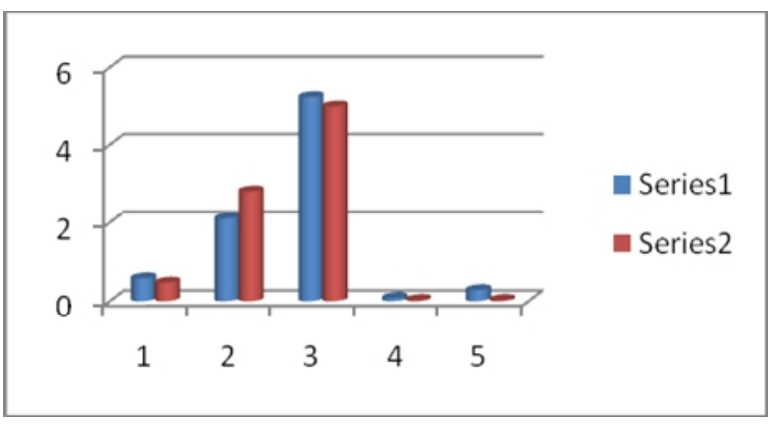

Bar Diagram 3: Analytical Study of Rasasindur And Chandrodaya Rasa 1.- Loss on Ignition, 2.Loss on drying at $110^{\circ} \mathrm{c}, 3$.Total ash, 4. Acid insoluble ash, 5 . Water soluble ash $\%$



Bar Diagram 2: Analytical Study of Kajjali And Suwarna Kajjali 1.Mercury as $\mathrm{Hg}$, 2.Sulphur as $\mathrm{S}$

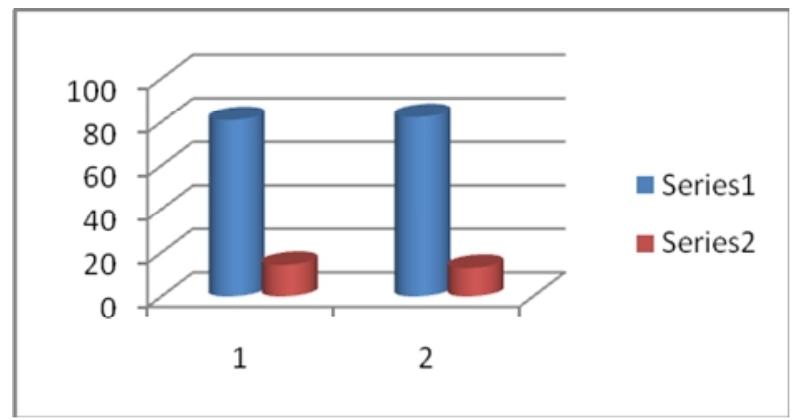

Bar Diagram 4: Analytical Study of Rasasindur And Chandrodaya Rasa 1.Mercury as $\mathrm{Hg}$, 2.Sulphur as $\mathrm{S}$ 


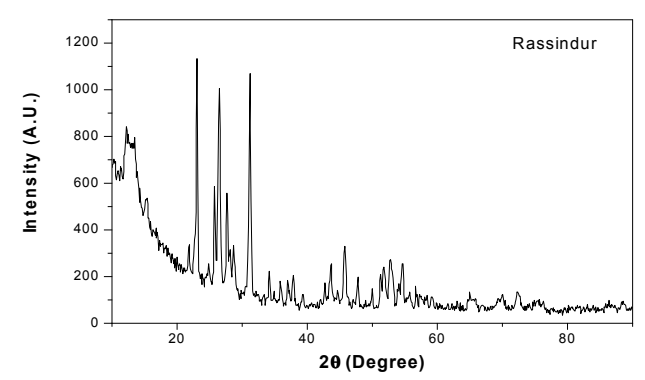

Graph 1: Rasasindura (XRD) *- HgS

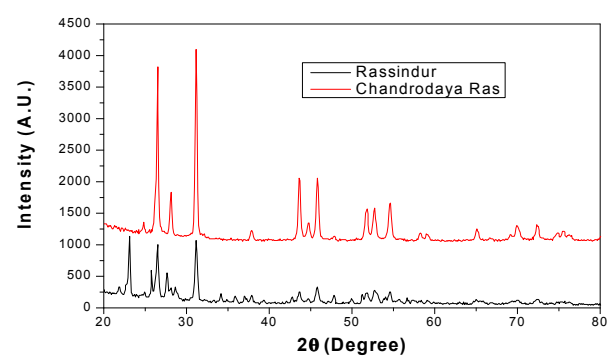

Graph 3: Comparative Graph of Rasasindura and Chandrodaya Rasa

\section{X-ray diffraction (XRD) studies}

$\mathrm{X}$-ray Diffrauction methods are based on the scattering of Xrays by crystals. They are used to identify the internal / crystal structures of the materials.

\section{Analysis of Rasasindur sample}

Rasasindur is shown to contain mercury sulfide (Hgs) associate with several organic macromolecules derived from the plant extract used during the processing of the drug. (Graph 1)

\section{Analysis of Chandrodayarasa sample}

Chandrodayarasa is also shown the picks of mercury sulfides (Hgs) and it shown picks of Gold ( $\mathrm{Au}$ ) in this sample with other several organic macromolecules. Gold is found in this sample is in trace amount. (Graph 2)

\section{DISCUSSION}

There are many methods described in text for therapeutic of mercury among these kupipakwa method is very unique and little difficult comparatively other. Classical literatures have given more importance for Gandhaka Jarana. Gandhaka jarana depends upon the quantity of Gandhaka and type of Agni i.e. more time requires for more quantity of Gandhaka, Generaly for 100 gm Gandhaka 12-14 hrs requires on bhatti and if agni by gas then it takes 8-10 hrs for jarana. There was

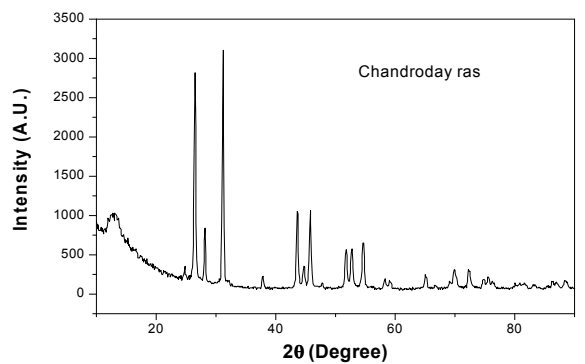

Graph 2: Chandrodaya Rasa (XRD) *- HgS, \# - Gold

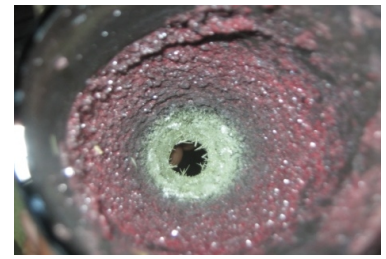

Rasasindura

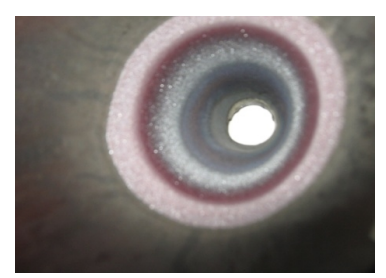

Chandrodaya Rasa a total loss of $6 \%$ during preparation of Samguna Kajjali, it may be due to process loss or human error. A maximum gain of $10 \mathrm{gm}$ out of $950 \mathrm{gm}$ of Kajjali was observed in Vatankura swarasa Bhavana practical. Among the Rasasindura maximum 76 gm of Rasasindura was obtained out of $200 \mathrm{gm}$ of Kajjali i.e.38\% yield. During the Chandrodayarasa maximum 42 gm of Kanthastha part was obtained out of 120 gm of Kajjali.i.e.35\% yield. Preparation of Amalgam of Gold and Parada is depends upon the thinness of Suwarnapatra, the gold foil is best for it or in market powder of Gold or Varkha is best for easy mixing in Parada. Weight of Parada is not increased. For The Mardana of This Mixure never use metal Khalwa, only use Stone or Porcelain Kalwa to prevent the loss of Gold.

\section{REFERENCES}

1. Sadanand Sharma,Ras-tarangini,Motilal Banarasdas Prakashan- 11th edition, 6/162-167 p 135-136

2. Shri. Vagbhattacharya virachit, Rasaratnasamuchchaya edited by Kaviraj Shri Ambikadatta Shastri, Choukhamba Amarbharati Prakashan - Varanasi,chapter 9/33-35 p151

3. Shri Gopalkrishna Bhatt,Rasendra Sar Sangraha, Motilal Banarasdas Prakashan, $4^{\text {th }}$ edition, Varanasi. Rasayan chapter.65-70, p 627-628.

Cite this article as:

Ingole Rajesh.Kundlikrao, Khaparde Prakash Hiralal. Pharmaceutical and analytical study of Rasasindura chandrodaya rasa. Int. Res. J. Pharm. 2013; 4(4):123-125 